\title{
EFFECTIVENESS OF COURSE DELIVERY METHODS: A MULTI-UNIVERSITY STUDY
}

\author{
Paul Kovacs, Robert Morris University, kovacs@rmu.edu \\ Alan Peslak, Penn State University, arp14@psu.edu \\ Lisa Kovalchick, California University of Pennsylvania, kovalchick@calu.edu \\ Wenli Wang, Robert Morris University, wangw@rmu.edu \\ Gary Alan Davis, Robert Morris University, davis@rmu.edu
}

\begin{abstract}
Courses and programs delivered in the online format continue to grow and institutions of higher education have committed increasing resources for the development of online classes and even entire degree programs. Yet many questions remain concerning the practicality and reliability of online learning, particularly from the student's perspective. The purpose of this study was to collect insights into students' perceptions of online learning as compared to those of the traditional on-ground learning and hybrid learning formats. This study surveyed 287 students enrolled in computer and information systems courses from three universities to identify perceived challenges based on their online learning experiences. Results of the study indicated that students find completely online courses less effective than on-ground and hybrid courses. This finding is consistent across three universities, a private university, a state university, and a state-related university.
\end{abstract}

Keywords: Online Education, Perceived Learning, Higher Education, Computer Information Systems

\section{INTRODUCTION}

Online education has emerged as a fundamental influence in educational delivery systems, particularly in higher education. In the first decade of the $21^{\text {st }}$ century, the number of students taking at least one fully online class from an accredited university in the United States has grown considerably (Armstrong, 2010). According to a Sloan Consortium survey of 2,500 U.S. colleges and universities, online enrollments have increased from about 1.6 million in 2002 to 5.8 million in 2014. Of these 5.8 million, 2.85 million were taking all the courses online, and 2.97 million were taking some of their courses online (Allen \& Seaman, 2015). The observed growth rate from 2013 to 2014 of the number of students taking at least one online course was $3.9 \%$, up from the $3.7 \%$ rate for the previous year. The number of students not taking any distance education courses continues to drop, down 434,236 from 2012 to 2013, and a further 390,815 from 2013 to 2014. Additionally, the number of institutions in the U.S. offering university-level, pure online as well as hybrid/blended online courses, has reached as many as 2,700 (Kim, Kwon, Cho, 2011). In addition to programs and courses, many universities currently require online access to basic course information, such as the syllabus, assignments and other resources. Even when not mandated by their institutions, educators are increasingly developing a presence for their courses on the Internet (Smart \& Cappel, 2006).

Although online learning (and various hybrid delivery methods that integrate online components into traditional classes) continues to grow rapidly, many questions remain concerning the practicality and reliability of online learning, particularly from the student's perspective. Consequently, developers of online courses and programs need more understanding of how students perceive online learning.

The purpose of this study is to collect insights into students' perceptions of online learning, as compared to the traditional on-ground learning and hybrid learning formats. The results could raise important considerations about using online course delivery for Computer and Information Systems (CIS) instruction. Specifically, the study seeks to answer the following research questions: 
RQ1. What is the current preferred course delivery method (online or on-ground) for CIS students and are there differences by school?

RQ2. How do current students rate the overall effectiveness of courses delivered completely online and are there differences by school?

RQ3. How do current students rate the overall effectiveness of courses delivered via hybrid methods (i.e., partially online and partially on-ground) and are there differences by school?

RQ4. How do current students rate the overall effectiveness of courses delivered on-ground (or on-ground with online supplements) and are there differences by school?

RQ5. Do current students rate overall effectiveness significantly different based on delivery mode?

\section{DEFINITION OF TERMS}

There are many terms used to describe the various learning delivery methods. For the purposes of this research, an online course (also defined as e-learning, distance learning or web-based learning) is defined as one in which 100 percent of the course content is delivered online, with no face-to-face meetings. An on-ground course (traditional or "face-to-face" instruction) is defined as a course in which zero percent of the content is delivered online. A hybrid course (also called blended learning or partially online learning) involves a course that is partially delivered online and partially delivered in the classroom (i.e., between 30 percent and 80 percent of the course content is delivered online). Finally, a course that incorporates Web-based technology, such as posting the syllabus and assignments online to facilitate what is essentially an on-ground course, is defined as "on-ground with an on-line supplement." A number of courses that incorporate Web-based supplements, such as podcasting, "wikis" and blogs, threaded discussions and Web-based assignments are frequently considered to be online courses. Courses that make use of these Web-based supplements are not considered online courses for this research but are, instead, regarded as traditional (hybrid/partially online) courses with online components or supplements.

\section{STUDENTS' PERCEPTIONS AND EXPECTATIONS}

A study by Dobbs, Waid and del Carmen (2009) measured students' perceptions of online course experiences and found that more students regarded traditional face-to-face courses to be easier than online classes. The participants of the study consisted of 180 students who were enrolled in online courses and 100 students who were enrolled in traditional, "face-to-face" (on-ground) courses. The authors found that more students perceived the traditional "faceto-face" courses to be easier than online classes. Student views about online education varied greatly between those who had never taken an online class and those who had actually taken such courses. Those students with no online class experience felt that the faculty would have low expectations, but students who had taken at least one online course believed that high expectations were common with faculty. The study also found that the acceptance of online education increased as the number of online courses taken increased.

Hannay and Newvine (2006) Utilizing a 22-question survey with 217 respondents, who were primarily adult, parttime students enrolled in criminal justice courses, found that students who had never taken an online course were not as confident that they could do as well in an online course as they would in an on-ground, "face-to-face," course. Additionally, the authors found that students must possess greater discipline to succeed in an online course, that students thought the online course would not cover the material in the same magnitude as the "face-to-face" course, and that students were skeptical about the opportunity of interaction with classmates in an online course.

In their study involving undergraduate management courses, Drennan, Kennedy and Pisarski (2005) found that research subjects believed it was important to achieve a balance between the use of traditional, "face-to-face," lectures and emerging technologies.

Allen, Bourhis, Burrell, and Mabry (2002) found that students had similar levels of satisfaction when it came to online education and the face-to-face approach. Regarding student performance in online vs. traditional sections of an undergraduate management classes a study by Daymont and Blau (2008) found that undergraduate students performed equally well in both online and traditional settings. In another study, Parker (2003) found that most first year students 
majoring in Information Technology and Information Systems perceived online education as more fun and of a higher quality than traditional venues. In addition, these students believed that course information was easy to access and that this contributed to their academic success. Howland and Moore (2002) reported that students' expectations were a determining influence on their online course experience and strategies and that self-management, self-monitoring, and individual motivations were key factors for success in online classes.

Cole, Shelley, and Swartz (2014) did a three-year study involving 553 undergraduate and graduate students enrolled in business degree programs. The Cole et al. study sought to determine how satisfied students were with both online and partially online (i.e., hybrid) courses. Their study also sought to determine the factors that contribute to student satisfaction and dissatisfaction with online course delivery methods. Their study found that, overall, students were moderately satisfied with fully-online classes. However, the study revealed that the participants were slightly more satisfied with hybrid/partially-online courses. The students reported "Convenience" as the factor that contributed most to satisfaction. "Lack of interaction" (with both the professor and other students) was cited as the factor that contributed most to dissatisfaction with online courses (p. 122).

Ilgaz and Gülbahar (2015) developed a research model that involved "e-Readiness" and "e-Satisfaction." The authors' model was developed as a way to comprehensively measure students' readiness before taking online courses, and students' resulting satisfaction after taking online classes. After surveying over 1,500 undergraduate and graduate students, the authors discovered that students begin online classes with specific expectations; therefore, meeting or not meeting these expectations directly impacts students' satisfaction levels. Students expect to have an effective learning experience that emulates the physical classroom by "...interacting with the instructors and other participants" (p. 183). The authors also found that students are most satisfied with online classes if their expectations regarding "instructional content, communication and usability, and teaching process" were met by their online learning experience (p. 183).

Vidanagama (2016) conducted a study involving 209 undergraduate students enrolled in computer-related degrees. The author used the Technology Acceptance Model (TAM) to determine if several factors associated with online learning (e.g., perceived attitude, perceived enjoyment, and perceived usefulness) are affected by technology. The author determined that, among computing students, the perceptions of online courses can be affected by technological adequacy and ease of use. According to the study, students in computing degrees are more satisfied with online learning when the technological environment (Learning Management System, software used in courses, etc.) performs adequately and is easy to use. It can be inferred from this study that students in computing fields are more critical (than students in other degree fields) of the technological environment involved in online course delivery. This finding creates an additional challenge for educators who teach computer-related subjects in an online or partially-online environment.

Finally, a comprehensive 12-year experimental and quasi-experimental study utilizing meta-analysis conducted by the U.S. Department of Education found that a blend of online and "face-to-face" instruction has been more effective, which provides a rationale for the effort required to design and implement blended approaches (Means, Toyama, Murphy, Bakia \& Jones, 2009). This research also indicated that, despite what appears to be strong support for online learning applications, the studies in this meta-analysis do not demonstrate that online learning is superior as a medium. In many of the studies that involved a preference for online learning, the online and classroom conditions differed in terms of time spent, curriculum and pedagogy.

Overall, then, the research has been mixed as to effectiveness of online course delivery. Our study is an up-to-date survey of current University students across three different types of universities (state, private, and state-related) and attempts to reach a current consensus from a student's perspective on the effectiveness of online education versus hybrid and on-ground.

\section{RESEARCH METHODOLOGY}

This study involved an online survey instrument that consisted of 34 closed-ended questions. The survey was administered to students enrolled in Computer Information Systems (CIS) courses at three universities; one private, 


\section{Issues in Information Systems \\ Volume 18 Issue 1, pp. 137-147, 2017}

one state-owned, and one state-related. The students at the private university included those seeking bachelor's, master's and doctoral degrees. The students at the state-owned university and the state-related university only included those seeking a bachelor's degree. A state-related school is one which does receive funding from the state but it is only a small portion of total revenue as opposed to a state school which receives a major function of its funding from the state and has substantially lower tuition. We succeeded to obtain a mix of respondents from different types of universities because of potential different demographics of each group. Norvilitis, J. M., Merwin, M. M., Osberg, T. M., Roehling, P. V., Young, P., \& Kamas, M. M. (2006) found many demographic differences between state and private university students including debt to income ratio and a significant disparity in race.

A total of 287 students responded to the survey. Actual number of responses to each question varied by question. The respondents used QuestionPro survey software to submit their results directly into an electronic database for analysis. To address the research questions, statistical frequencies and statistical tests were conducted in Statistical Package for the Social Sciences (SPSS 22.0) statistical software.

\section{RESULTS}

\section{Demographics}

The first part of the analysis of results uses frequency tables to present the general demographics of the online survey participants. As noted, the survey responses were received from three major U.S. universities. As shown in Table 1, out of a total of 287 responses, $91.6 \%$ of the results were valid with $29 \%$ of the responses from the state-owned university, $22 \%$ from the state-related university and $49 \%$ from the private university. These universities provide a diverse, socio-economic mix of participants.

Table 1. Frequency table results of the survey question "I am currently attending (or have attended) the following college/university. (If multiple schools apply, select the most current)."

\begin{tabular}{|l|l|r|r|r|r|}
\hline \multicolumn{2}{|c|}{} & Frequency & Percent & Valid Percent & Cumulative Percent \\
\hline \multirow{5}{*}{ Valid } & State U. & 75 & 26.1 & 28.5 & 28.5 \\
\cline { 2 - 6 } & State-related U. & 58 & 20.2 & 22.1 & 50.6 \\
\cline { 2 - 6 } & Private U. & 130 & 45.3 & 49.4 & 100.0 \\
\cline { 2 - 6 } & Total & 263 & 91.6 & 100.0 & \\
\hline Missing & System & 24 & 8.4 & & \\
\hline \multicolumn{2}{|l|}{ Total } & 287 & 100.0 & & \\
\hline
\end{tabular}

Due to the inherent gender bias in CIS programs, the ratio of male to female students who took the survey was fairly high, as shown in Table 2, $81 \%$ of the survey respondents were male, $18 \%$ were female and $1 \%$ identified as other.

Table 2. Frequency table results of the survey question "Please indicate your gender ..."

\begin{tabular}{|l|l|r|r|r|r|}
\hline \multicolumn{2}{|c|}{} & Frequency & Percent & Valid Percent & Cumulative Percent \\
\hline \multirow{5}{*}{ Valid } & Male & 177 & 61.7 & 80.8 & 80.8 \\
\cline { 2 - 6 } & Female & 40 & 13.9 & 18.3 & 99.1 \\
\cline { 2 - 6 } & Other & 2 & .7 & .9 & 100.0 \\
\cline { 2 - 6 } & Total & 219 & 76.3 & 100.0 & \\
\hline Missing & System & 68 & 23.7 & & \\
\hline \multicolumn{2}{|l|}{ Total } & 287 & 100.0 & & \\
\hline
\end{tabular}

The age group was also skewed with the population, as shown in Table 3, 49\% of the students who took the survey were between 18 and 21 years of age and another $28 \%$ were between 22 and 30 years of age. The over 30 population consisted of $23 \%$ of survey respondents. 
Table 3. Frequency table results of the survey question "Please indicate your age range ..."

\begin{tabular}{|l|l|r|r|r|r|}
\hline \multicolumn{2}{|c|}{} & \multicolumn{1}{c|}{ Frequency } & \multicolumn{1}{c|}{ Percent } & \multicolumn{1}{c|}{ Valid Percent } & \multicolumn{1}{c|}{ Cumulative Percent } \\
\hline \multirow{4}{*}{ Valid } & $18-21$ & 104 & 36.2 & 47.3 & 47.3 \\
\cline { 2 - 6 } & $22-30$ & 64 & 22.3 & 29.1 & 76.4 \\
\cline { 2 - 6 } & $31-40$ & 33 & 11.5 & 15.0 & 91.4 \\
\cline { 2 - 6 } & $41-50$ & 9 & 3.1 & 4.1 & 95.5 \\
\cline { 2 - 6 } & $51-60$ & 8 & 2.8 & 3.6 & 100.1 \\
\cline { 2 - 6 } & Over 60 & 2 & .7 & .9 & \\
\cline { 2 - 6 } & Total & 220 & 76.7 & 100.0 & \\
\hline Missing & System & 67 & 23.3 & & \\
\hline \multicolumn{1}{|l}{ Total } & 287 & 100.0 & & \\
\hline
\end{tabular}

Research Question 1: "What is the current preferred course delivery method (online or on-ground) for CIS students and are there differences by school?"

Early in our survey an initial question was asked that just addressed whether students preferred online to on-ground classes. A distinction was not made for hybrid classes. We just wanted to initially obtain a reaction on a simple choice question. We further refine this in subsequent questions. To answer the first part of this research question, a frequency table was used to analyze results of the survey question "If given a choice to take the same course in an online format or an on-ground format, would you select the online format?" The survey yielded surprising results, as shown in Table 4 . Even though $54 \%$ of students preferred traditional on-ground course delivery, a full $46 \%$ preferred the online format. This differs with a recent 2013 study by USA Today (Karembelas, 2013) that found that 78\% of students prefer on-ground courses. One possible difference for this may be the technology savvy nature of CIS students. Among the reasons expressed for this preference, the two primary motives reported were convenience and scheduling.

Table 4. Frequency table results of the survey question "If given a choice to take the same course in an online format or an on-ground format, would you select the online format?"

\begin{tabular}{|l|l|r|r|r|r|}
\hline \multicolumn{2}{|c|}{} & Frequency & \multicolumn{1}{c|}{ Percent } & Valid Percent & Cumulative Percent \\
\hline \multirow{3}{*}{ Valid } & Online & 122 & 42.5 & 46.4 & 46.4 \\
\cline { 2 - 6 } & On ground & 141 & 49.1 & 53.6 & 100.0 \\
\cline { 2 - 6 } & Total & 263 & 91.6 & 100.0 & \\
\hline Missing & System & 24 & 8.4 & & \\
\hline \multicolumn{2}{|c|}{ Total } & 287 & 100.0 & & \\
\hline
\end{tabular}

To answer the second part of this research question, descriptive statistics, based on University type, of the survey question "If given a choice to take the same course in an online format or an on-ground format, would you select the online format?" were analyzed. As shown in Table 5, little difference was found based on the student's university. There was no significant difference between the state-owned and private university and the private university and state-related university at $\mathrm{p}<.05$.

Table 5. University Type Descriptive Statistics of the survey question: "If given a choice to take the same course in an online format or an on-ground format, would you select the online format?

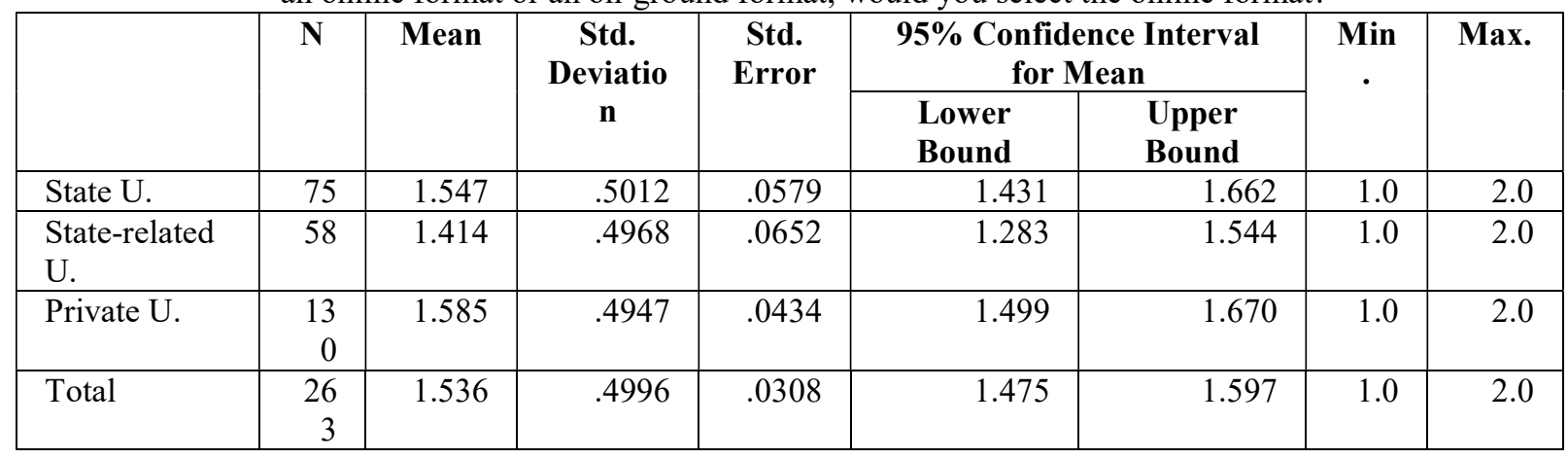


Research Question 2: How do current students rate the overall effectiveness of courses delivered completely online and are there differences by school?

To answer the first part of this question, a frequency table was used to analyze the results of a survey question which asked the students to rate their perception of the overall effectiveness of courses that are offered completely online. As shown in Table 6, in general, effectiveness of online courses is moderate in our survey. Although $73.4 \%$ of the students surveyed found the online offering of courses at least somewhat effective, only $8.9 \%$ found them very effective.

Table 6. Frequency table results of the survey question: "Do you perceive the overall effectiveness of courses that are offered completely online as..."

\begin{tabular}{|l|l|r|r|r|r|}
\hline \multicolumn{1}{|c|}{} & Frequency & Percent & Valid Percent & Cumulative Percent \\
\hline Valid & Very effective & 15 & 5.2 & 8.9 & 8.9 \\
\cline { 2 - 6 } & Effective & 56 & 19.5 & 33.1 & 42.0 \\
\cline { 2 - 6 } & Somewhat effective & 53 & 18.5 & 31.4 & 73.4 \\
\cline { 2 - 6 } & $\begin{array}{l}\text { Somewhat } \\
\text { ineffective }\end{array}$ & 24 & 8.4 & 14.2 & 87.6 \\
\cline { 2 - 6 } & Ineffective & 15 & 5.2 & 8.9 & 96.4 \\
\cline { 2 - 6 } & Very ineffective & 6 & 2.1 & 3.6 & 100.0 \\
\cline { 2 - 6 } & Total & 169 & 58.9 & 100.0 & \\
\hline Missing & System & 118 & 41.1 & & \\
\hline Total & & 287 & 100.0 & & \\
\hline
\end{tabular}

To answer the second part of this research question, descriptive statistics, based on University type, of the survey question "Do you perceive the overall effectiveness of courses that are offered completely online as..." were analyzed. Results shown in Table 7, show little difference between the three types of universities. One-way ANOVA analysis was performed as well as Post Hoc Analysis between pairs of variables. None of these differences were significant at $\mathrm{p}<.05$.

Table 7. University Type Descriptive Statistics of the survey question "Do you perceive the overall effectiveness of courses that are offered completely online as..."

\begin{tabular}{|l|c|c|c|c|c|c|c|c|}
\hline & $\mathbf{N}$ & Mean & \multirow{2}{*}{$\begin{array}{c}\text { Std. } \\
\text { Deviation }\end{array}$} & \multicolumn{2}{|c|}{$\begin{array}{c}\text { Std. } \\
\text { Error }\end{array}$} & & & \multicolumn{2}{|c|}{$\begin{array}{c}\text { 95\% Confidence Interval for } \\
\text { Mean }\end{array}$} & Min. & Max. \\
\cline { 5 - 8 } & & & & & Lower Bound & \multicolumn{2}{|c|}{$\begin{array}{c}\text { Upper } \\
\text { Bound }\end{array}$} & \\
\hline State U. & 61 & 3.197 & 1.3269 & .1699 & 2.857 & 3.537 & 1.0 & 6.0 \\
\hline $\begin{array}{l}\text { State-related } \\
\text { U. }\end{array}$ & 41 & 2.829 & 1.0701 & .1671 & 2.492 & 3.167 & 1.0 & 5.0 \\
\hline Private U. & 67 & 2.716 & 1.1910 & .1455 & 2.426 & 3.007 & 1.0 & 6.0 \\
\hline Total & 169 & 2.917 & 1.2268 & .0944 & 2.731 & 3.103 & 1.0 & 6.0 \\
\hline
\end{tabular}

Research Question 3: How do current students rate the overall effectiveness of courses delivered via hybrid methods (partially online and partially on-ground) and are there differences by school?

To answer the first part of this question, a frequency table was used to analyze the results of a survey question which asked the students to rate their perception of the overall effectiveness of courses that are offered partially online and partially on-ground (i.e., hybrid). As shown in Table 8, in general, in our survey, perceived effectiveness of hybrid courses is higher than perceived effectiveness of completely online courses. Fifty-six percent of the students surveyed found the hybrid offering effective or very effective; however, $46 \%$ found hybrid delivery somewhat effective or less. 
Table 8. Frequency table results of the survey question: "Do you perceive the overall effectiveness of courses that are offered partially online and partially on-ground (i.e., hybrid) as ..."

\begin{tabular}{|l|l|r|r|r|r|}
\hline \multicolumn{2}{|c|}{} & Frequency & Percent & Valid Percent & Cumulative Percent \\
\hline \multirow{7}{*}{ Valid } & Very effective & 23 & 8.0 & 13.8 & 13.8 \\
\cline { 2 - 6 } & Effective & 71 & 24.7 & 42.5 & 56.3 \\
\cline { 2 - 6 } & Somewhat effective & 46 & 16.0 & 27.5 & 83.8 \\
\cline { 2 - 6 } & Somewhat ineffective & 15 & 5.2 & 9.0 & 92.8 \\
\cline { 2 - 6 } & Ineffective & 7 & 2.4 & 4.2 & 100.0 \\
\cline { 2 - 6 } & Very ineffective & 5 & 1.7 & 3.0 & \\
\cline { 2 - 6 } & Total & 167 & 58.2 & 100.0 & \\
\hline \multicolumn{1}{|l|}{ Missing } & System & 120 & 41.8 & & \\
\hline \multicolumn{2}{|l|}{ Total } & 287 & 100.0 & & \\
\hline
\end{tabular}

To answer the second part of this research question, descriptive statistics, based on University type, of the survey question "Do you perceive the overall effectiveness of courses that are offered partially online and partially on-ground (i.e., hybrid) as ..." As shown in Table 9, there are small differences in effectiveness perception by university type The private university showed the highest level of effectiveness followed by the state-related and the state-owned university. One-way ANOVA analysis was performed as well as Post Hoc Analysis between pairs of variables. None of these differences were statistically significant.

Table 9. University Type Descriptive Statistics of the survey question "Do you perceive the overall effectiveness of courses that are offered partially online and partially on-ground as ..."

\begin{tabular}{|l|c|c|c|c|c|c|c|c|}
\hline & \multirow{2}{*}{} & N & Mean & \multirow{2}{*}{$\begin{array}{c}\text { Std. } \\
\text { Deviation }\end{array}$} & \multirow{2}{*}{$\begin{array}{c}\text { Std. } \\
\text { Error }\end{array}$} & & & \multicolumn{2}{|c|}{$\begin{array}{c}\text { 95\% Confidence Interval for } \\
\text { Mean }\end{array}$} & Min. & Max. \\
\cline { 5 - 8 } & & & & $\begin{array}{c}\text { Lower } \\
\text { Bound }\end{array}$ & $\begin{array}{c}\text { Upper } \\
\text { Bound }\end{array}$ & & \\
\hline State U. & 59 & 2.831 & 1.2751 & .1660 & 2.498 & 3.163 & 1.0 & 6.0 \\
\hline $\begin{array}{l}\text { State-related } \\
\text { U. }\end{array}$ & 41 & 2.537 & .9246 & .1444 & 2.245 & 2.828 & 1.0 & 5.0 \\
\hline Private U. & 67 & 2.343 & 1.1221 & .1371 & 2.070 & 2.617 & 1.0 & 6.0 \\
\hline Total & 16 & 2.563 & 1.1488 & .0889 & 2.387 & 2.738 & 1.0 & 6.0 \\
\hline
\end{tabular}

Research Question 4: How do current students rate the overall effectiveness of courses delivered on-ground (or on-ground with online supplements) and are there differences by school?

To answer the first part of this question, a frequency table was used to analyze the results of a survey question which asked the students to rate their perception of the overall effectiveness of courses that are offered on-ground with an online supplement (i.e., online materials provided on Blackboard or an instructor's website). As shown in Table 10, in general, the effectiveness of on-ground courses is highest in our survey. Seventy-four percent of the students surveyed found the on-ground offering effective or very effective and only $26 \%$ found on-ground delivery somewhat effective or less. 
Table 10. Frequency table results of the survey question: "Do you perceive the overall effectiveness of courses that are offered on-ground but have an online supplement (i.e., online materials provided on Blackboard or an instructor's website) as...

\begin{tabular}{|c|c|c|c|c|c|}
\hline & & Frequency & Percent & Valid Percent & Cumulative Percent \\
\hline \multirow[t]{7}{*}{ Valid } & $\begin{array}{l}\text { Very } \\
\text { effective }\end{array}$ & 52 & 18.1 & 31.1 & 31.1 \\
\hline & Effective & 72 & 25.1 & 43.1 & 74.3 \\
\hline & $\begin{array}{l}\text { Somewhat } \\
\text { effective }\end{array}$ & 30 & 10.5 & 18.0 & 92.2 \\
\hline & $\begin{array}{l}\text { Somewhat } \\
\text { ineffective }\end{array}$ & 5 & 1.7 & 3.0 & 95.2 \\
\hline & Ineffective & 6 & 2.1 & 3.6 & 98.8 \\
\hline & $\begin{array}{c}\text { Very } \\
\text { ineffective }\end{array}$ & 2 & .7 & 1.2 & 100.0 \\
\hline & Total & 167 & 58.2 & 100.0 & \\
\hline Missing & System & 120 & 41.8 & & \\
\hline \multicolumn{2}{|l|}{ Total } & 287 & 100.0 & & \\
\hline
\end{tabular}

To answer the second part of this research question, descriptive statistics, based on University type, were used to describe the survey question "Do you perceive the overall effectiveness of courses that are offered on-ground but have an online supplement (i.e., online materials provided on Blackboard or an instructor's website) as ..." As shown in Table 11, the private university showed the highest level of effectiveness followed by the state-related and the stateowned university. One-way ANOVA analysis was performed as well as Post Hoc Analysis between pairs of variables. None of these differences were statistically significant.

Table 11. University Type Descriptive Statistics of the survey question "Do you perceive the overall effectiveness of courses that are offered on-ground but have an online supplement (i.e., online materials provided on Blackboard or an instructor's website) as..."

\begin{tabular}{|c|c|c|c|c|c|c|c|c|}
\hline & \multirow[t]{2}{*}{$\mathbf{N}$} & \multirow[t]{2}{*}{ Mean } & \multirow[t]{2}{*}{$\begin{array}{c}\text { Std. } \\
\text { Deviation }\end{array}$} & \multirow[t]{2}{*}{$\begin{array}{l}\text { Std. } \\
\text { Error }\end{array}$} & \multicolumn{2}{|c|}{$\begin{array}{l}\text { 95\% Confidence Interval } \\
\text { for Mean }\end{array}$} & \multirow[t]{2}{*}{ Min. } & \multirow[t]{2}{*}{ Max. } \\
\hline & & & & & $\begin{array}{l}\text { Lower } \\
\text { Bound }\end{array}$ & $\begin{array}{l}\text { Upper } \\
\text { Bound }\end{array}$ & & \\
\hline State U. & 59 & 2.271 & 1.2010 & .1564 & 1.958 & 2.584 & 1.0 & 6.0 \\
\hline $\begin{array}{l}\text { State-related } \\
\text { U. }\end{array}$ & 41 & 2.171 & .8337 & .1302 & 1.908 & 2.434 & 1.0 & 4.0 \\
\hline Private U. & 67 & 1.866 & 1.0283 & .1256 & 1.615 & 2.116 & 1.0 & 6.0 \\
\hline Total & $\begin{array}{r}16 \\
7\end{array}$ & 2.084 & 1.0609 & .0821 & 1.922 & 2.246 & 1.0 & 6.0 \\
\hline
\end{tabular}

\section{Research Question 5: Do current students rate overall effectiveness significantly different based on delivery} mode?

General Linear Model Repeated Measures were used to explore Research Question 5. GLM measures the same unit (here person) in various situations (questions). As shown in Tables 12 and 13, overall, it was found that the effectiveness differences found between online, hybrid and on-ground courses were small and via Greenhouse-Geisser test found to be statistically significant at $p<.001$. Completely online was found to be somewhat effective, on-ground to be effective and hybrid to be somewhere in between. The gap between perception of effectiveness of online and hybrid courses still significantly trails that of traditional on-ground courses. 
Table 12. Effectiveness of Course Delivery Methods Descriptive Statistics

\begin{tabular}{|c|c|c|c|}
\hline & Mean & Std. Deviation & $\mathbf{N}$ \\
\hline $\begin{array}{l}\text { "Do you perceive the overall effectiveness of courses that are } \\
\text { offered completely online as..." }\end{array}$ & 2.922 & 1.2321 & 167 \\
\hline $\begin{array}{l}\text { "Do you perceive the overall effectiveness of courses that are } \\
\text { offered partially online and partially on-ground (i.e., hybrid) as.." }\end{array}$ & 2.563 & 1.1488 & 167 \\
\hline $\begin{array}{l}\text { "Do you perceive the overall effectiveness of courses that are } \\
\text { offered on-ground but have an online supplement (i.e., online } \\
\text { materials provided on Blackboard or on an instructor's website) } \\
\text { as..." }\end{array}$ & 2.084 & 1.0609 & 167 \\
\hline
\end{tabular}

\begin{tabular}{|c|c|c|c|c|c|c|}
\hline \multicolumn{7}{|c|}{ Table 13: Tests of Within-Subjects Effects } \\
\hline Measure & it Perceived Effective & of Delivery Mc & & & & \\
\hline \multicolumn{2}{|l|}{ Source } & $\begin{array}{l}\text { Type III Sum } \\
\text { of Squares }\end{array}$ & Df & Mean Square & $\mathrm{F}$ & Sig. \\
\hline \multirow[t]{4}{*}{ factor 1} & Sphericity Assumed & 59.082 & 2 & 29.541 & 28.656 & .000 \\
\hline & Greenhouse-Geisser & 59.082 & 1.817 & 32.520 & 28.656 & .000 \\
\hline & Huynh-Feldt & 59.082 & 1.836 & 32.183 & 28.656 & .000 \\
\hline & Lower-bound & 59.082 & 1.000 & 59.082 & 28.656 & .000 \\
\hline
\end{tabular}

\section{CONCLUSIONS}

This study confirmed that, when given a choice, most students prefer on-ground course delivery over online course delivery. Other studies found this preference among students to be greater than what was found in the current study. However, this difference may be attributed to the technology-savvy nature of the Computer and Information Systems majors in the current study. No significant difference in delivery method preference was found among students attending the three universities in the study.

There was, however, a statistically significant difference regarding the effectiveness of the course delivery format. The effectiveness of on-ground (but with an online supplement) was found to be significantly higher than the effectiveness of the hybrid/partially-online format. Additionally, the effectiveness of the hybrid/partially-online format was found to be significantly higher than that of the completely online format. As in the other findings in the current research, the students' effectiveness ratings did not differ significantly by the university attended. It is clear from the current study that there is a quality -gap in perceived effectiveness between online and on-ground course delivery methods.

The content of CIS courses must be considered in regard to the current research findings. This study surveyed only students who were enrolled in CIS courses. Since CIS courses involve content that is technical as well as quantitative, some students may have difficulty comprehending such content in an online format. Furthermore, although the online format may be selected by a self-disciplined student, it may be an inappropriate format for a more dependent student. Therefore, those designing and/or teaching CIS courses in the on-line format may need to assess whether their intended students have motivation, commitment, and time management skills to take such a course in that format. Many students in this study may have selected the on-ground delivery method because they have less difficulty with this type of learning and may require a high degree of interaction with an instructor.

Finally, as online learning continues to gain popularity, faculty must be equipped to help students achieve success. Efforts should be made to further study the specific reasons behind the lack of perceived effectiveness of online instruction. 


\section{REFERENCES}

Allen, I. E., \& Seaman, J. (2015). 2015 Online Report Card - Tracking Online Education in the United States. Babson Survey Research Group and Quahog Research Group. Retrieved from https://onlinelearningconsortium.org/survey_report/2015-online-report-card-tracking-online-educationunited-states/

Allen, M., Bourhis, J., Burrell, N., \& Mabry, E. (2002). Comparing Student Satisfaction with Distance Education to Traditional Classrooms in Higher Education: A Meta-analysis. The American Journal of Distance Education, 16(2), 83-97.

Armstrong, D. A. (2011). Students' perceptions of online learning and instructional tools: A qualitative study of undergraduate students' use of online tools. Turkish Online Journal of Educational Technology, 10(3), 222226. Retrieved from http://www.tojet.net/articles/v10i3/10325.pdf

Cole, M. T., Shelley, D. J., \& Swartz, L. B. (2014). Online instruction, e-learning, and student satisfaction: A three year study. International Review of Research in Open and Distance Learning, 15(6).

Daymont, T., \& Blau, G. (2008). Student Performance in Online and Traditional Sections of an Undergraduate Management Course. Journal of Behavioral and Applied Management, 9(3), 275-294.

Dobbs, R. R., Waid, C. A., \& del Carmen, A. (2009). Students' perceptions of online courses the effect of online course experience. The Quarterly Review of Distance Education, 10(1), 9-26.

Downing, K., \& Chim, T. M. (2004). Reflectors as online extraverts? Educational Studies, 30(3), 265-276.

Drennan, J., Kennedy, J., \& Pisarski, A. (2005). Factors affecting student attitudes toward flexible online learning in management education. Journal of Educational Research, 98(6), 331-339.

Hannay, M., \& Newvine, T. (2006). Perceptions of Distance-Learning: A Comparison of Online and Traditional Learning. MERLOT Journal of Online Learning and Teaching, 2(1) 1-11. Retrieved from http://jolt.merlot.org/documents/MS05011.pdf

Howland, J., \& Moore, J. (2002). Student Perceptions as Distance Learners in Internet-Based Courses. Distance Education, 23(2), 183-195.

Ilgaz, H., \& Gülbahar, Y. (2015). A snapshot of online learners: E-readiness, e-satisfaction and expectations. International Review of Research in Open and Distance Learning, 16(2).

Johnson, S., Aragon, S., Shaik, N., \& Palma-Rivas, N. (2000). Comparative Analysis of Learner Satisfaction and Learning Outcomes in Online and Face-to-Face Learning Environments. Journal of Interactive Learning Research, 11(1), 29-49.

Karambelas, D. (2013). Study: Students prefer real classrooms over virtual. https://www.usatoday.com/story/news/nation/2013/06/11/real-classrooms-better-than-virtual/2412401

Kim, J., Kwon, Y., \& Cho, D. (2011). Investigating factors that influence social presence and learning outcomes in distance higher education. Computers \& Education, 7(2), 1512-1520. doi:10.1016/j.compedu.2011.02.005

Means, B., Toyama, Y., Murphy, R., Bakia, M., \& Jones, K. (2010). Evaluation of Evidence-Based Practices in Online Learning: A Meta-Analysis and Review of Online Learning Studies, October 112010. 


\section{Issues in Information Systems}

Volume 18 Issue 1, pp. 137-147, 2017

Mitra, A. \& Steffensmeier, T. (2000).Changes in student attitudes and student computer use in a computer-enriched environment. Journal of Research on Technology in Education, 32(3), 417-433.

Norvilitis, J. M., Merwin, M. M., Osberg, T. M., Roehling, P. V., Young, P., \& Kamas, M. M. (2006). Personality factors, money attitudes, financial knowledge, and credit-card debt in college students1. Journal of Applied Social Psychology, 36(6), 1395-1413.

Parker, M. (2003). Technology-enhanced e-Learning: Perceptions of First Year Information Systems Students at the Cape Technikon. Proceedings of the South African Institute of Computer Scientists and Information Technologists, SAICSIT, 316-319.

Smart, K. L., \& Cappel, J. J. (2006). Students' perceptions of online learning: A comparative study. Journal of Information Technology Education, 5, 201-219.

Vidanagama, D. U. (2016). Acceptance of E-learning among undergraduates of computing degrees in Sri Lanka. International Journal of Modern Education and Computer Science, 8(4), 25-32. 